\title{
Role of Matrixmetalloproteinases in Periodontal Disease - A Review
}

\author{
Navjot Kaur Parmar, Nisha KJ*, Sanjeela Guru and Shyam Padmanabhan \\ Dept. of Periodontics, Vydehi Institute of Dental Sciences and Research Centre, India
}

Received: December 19, 2017; Published: January 05, 2018

*Corresponding author: Dr. Nisha KJ, Dept. of Periodontics, Vydehi Institute of Dental Sciences and Research Centre, EPIP Zone, Whitefield, Bangalore, Karnataka, India

\begin{abstract}
Matrixmetalloproteinases (MMPs) belong to family of proteolytic enzymes that cause degradation of extracellular matrix macromolecules, including interstitial and basement membrane collagens, fibronectin, laminin and proteoglycan core protein by secreting enzymes in latent form; which later gets activated in the pericellular environment by disruption of a $\mathrm{Zn++}$ cysteine bond. There is much evidence for the role of matrix metalloproteinases in the destructive processes of periodontal disease distinguishing them as a viable target for a chemotherapeutic approach. The use of a host modulatory agent such as a matrix metalloproteinase inhibitor can assist with conventional treatment for periodontitis and, when used adjunctively, can enhance and make clinical therapeutic responses more predictable in the more susceptible patient.
\end{abstract}

Keywords: Matrixmetalloproteinases; Periodontal disease; Inflammation

Abbreviations: MMPs: Matrixmetalloproteinases; ECM: Extracellular Matrix; GCF: Gingival Crevicular Fluid; IFMA: Immunofluorometric Assay

\section{Introduction}

Periodontal disease is a common, complex, inflammatory disease characterized by the destruction of tooth supporting soft and hard tissues of the periodontium, including alveolar bone and periodontal ligament. Although the inflammation is initiated by bacteria, the tissues breakdown events that lead to the clinical signs of disease result from the host inflammatory response that develops to combat the challenge presented by the subgingival biofilm. Microbial products trigger the release of pro inflammatory cytokines and host derived enzymes, the excessive and/or dysregulated production of which results in tissue breakdown. Once the immune and inflammatory processes are initiated and the complex cytokine network is established, various inflammatory molecules play a direct role in the degradation of both non mineralized and mineralized tissues of the periodontium. One such family of inflammatory molecules is the matrix metalloproteinases which are released from different cell types present in the lesion including macrophages, leukocytes and fibroblasts or other resident cells. Human MMPs also called as Matrixins, are a group of structurally related but genetically distinct endopeptidase enzymes. They are produced at low levels or not at all in restingstate adult tissues. Control of extracellular proteolysis by MMP is critically important for survival of organisms, and this is performed by interaction with various inhibitors like endogenous inhibitors,
TIMPs. This review article gives an overview of the physiological functions of MMPs and its role in the pathogenesis of periodontal diseases.

\section{History}

Study by Woessner [1] was considered as a milestone before the discovery of first MMP, Later in that year, Jerome Gross and Charles Lapiere [2] were the first to identify an MMP using a biochemical approach. In 1966, MMP-1 was purified from tadpole tail fin and back skin. MMP-2 was identified as a higher molecular mass species $(72 \mathrm{kDa})$ with gelatinolytic activity; purified from human rheumatoid synovial fibroblasts by Goldberg and colleagues whereas MMP-3 was identified as a lower molecular mass species ( $54 \mathrm{kDa}$ ) from rabbit synovial fibroblasts by the Werb laboratory in 1985 and subsequently named Stromelysin [3]. In the late 1980s, Ed Harris et al. [4] first proposed the name MMP. Subsequently, the International Union of Biochemistry and Molecular Biology designated the family with the unique name MMPs and assigned each family member with an enzyme number. To be classified as an MMP family member, the enzyme should meet the following requirements:

a) proteolysis of at least one extracellular matrix(ECM) component 

b) catalysis dependent on zinc at the active site
c) activation by proteinases or organomercurials
d) inhibited by EDTA,10-phenanthroline and any one of the TIMPs
e) cDNA has sequence homology to MMP-1

Initially it was thought that the proteinase be secreted in a proform but now this no longer holds as MMP-11 and MMP-28 are intracellular activated by furin and are secreted in active forms; even the membrane-bound MMPs are not necessarily secreted [5].

\section{Classification of MMP}

a. Based on the substrate specificity MMPs are classified into the following types [6].

b. Collagenases -MMP-1, MMP-8, MMP-13

c. Gelatinases- MMP-2, MMP-9

d. Stromelysins- MMP-3, MMP-10,MMP-11,MMP-12

e. Matrilysins- MMP-7, MMP-26

f. MT-MMPs (Membrane type) -MMP-14, MMP-15, MMP-16, MMP-17, MMP-24

g. Other MMPs- MMP-18,MMP-19,MMP-20, MMP-21,MMP23,MMP-27,MMP-28

\section{Domain Structure Of MMP}

MMPs are structurally similar but differ in substrate specificity. $\mathrm{T}$ he following features are seen in the structure [7]:
a. Signal peptide
b. Propeptide
c. Furin-cleavage site insert
d. Catalytic domain
e. Fibronectin-like repeats
f. Hinge region
g. Hemopexin domain
h. Membrane insertion extension

\section{Modes of Action}

Modes of action of MMPs are as follows [8]:

a. MMPs may affect cell migration by changing the cells from an adhesive to non adhesive phenotype and by degrading the ECM.

Table 1: Studies related to MMPs. b. MMPs may alter ECM microenvironment leading to cell proliferation, apoptosis, or morphogenesis.

c. MMPs may modulate the activity of biologically active molecules such as growth factors or growth factor receptors by cleaving them or releasing them from the ECM.

d. MMPs may alter the balance of protease activity by cleaving the enzymes or their inhibitors.

\section{Regulation of MMP Activity}

The activity of MMP against extracellular matrix substrates is regulated at 4 "gates" [9]:
I. Transcriptional regulation of MMP genes
II. Precursor activation
III. Differences in substrate specificity
IV. MMP inhibitors.

\section{Role of MMP in periodontal diseases}

In periodontal diseases, MMPs play key role in the degradation of the ECM, basement membrane and protective serpins as well as in the modification of cytokine action and activation of osteoclasts. Organisms like Porphyromonas gingivalis and Aggregatibacter actinomycetemcomitans do produce collagenases for the breakdown of ECM but they do not help much in periodontal collagen degradation. One way to differentiate between mammalian and bacterial collagenases is by their different mode of collagenolysismammalian collagenase cleaves the undenatured triple helical collagen molecule at a single site resulting in characteristic $3 / 4$ and $1 / 4$ fragments, whereas bacterial collagenase attacks the collagen substrate at multiple sites resulting in more than 200 peptide fragments. The extracellular matrix not only consists of collagen fibrils but also their associated proteoglycans and fibronectin which must be removed first in order for the collagenase to have access to the collagen substrate. MMP-3 (stromelysin) is effective at degrading proteoglycans and fibronectin [10].

Both resident gingival and periodontal ligament fibroblasts produce collagenases that are thought to be involved in normal tissue turnover. Inflammatory cells such as neutrophils and macrophages are also responsible for production of MMPs with neutrophils being the major source of collagenase and gelatinase in inflammatory diseases such as periodontitis [11,12]. Epithelial cells can also produce elevated levels of these enzymes, which may facilitate the apical migration and lateral extension of the junctional epithelium and the subsequent loss of connective tissue attachment [13]. The evidence for the role of MMPs in periodontal destruction is strong and has been supported over many years by a number of studies; few of them are quoted in the Table 1.

\begin{tabular}{|c|c|c|}
\hline Author and Year & Sample Taken And Processing Technique & Conclusion \\
\hline Azmak N et al. [14] & GCF by Immunofluorometric assay (IFMA) & $\begin{array}{c}\text { Chlorhexidine chip application following SRP is beneficial in } \\
\text { improving periodontal parameters and reducing GCF MMP-8 levels } \\
\text { for 6 months duration. }\end{array}$ \\
\hline
\end{tabular}




\begin{tabular}{|c|c|c|}
\hline Itagaki M et al. [15] & Genomic DNA by PCR & $\begin{array}{c}\text { MMP-1 and/or MMP-3 gene promoter polymorphisms did not } \\
\text { support the susceptibility to periodontitis in Japanese patients, } \\
\text { indicating MMP-1 and MMP-3 expressions were regulated by } \\
\text { complex processes such as cytokine network rather than gene } \\
\text { polymorphisms. }\end{array}$ \\
\hline Smith PC et al. [16] & Gingival Tissue By Immunofluorescence & $\begin{array}{c}\text { They found that the presence of pro MMP-9 in sulcular / pocket } \\
\text { epithelium derived from inflamed gingival tissues and scattered } \\
\text { along the connective tissues of periodontitis affected gingival } \\
\text { tissues. These observations suggest a role for MMP-9 in gingival } \\
\text { epithelial response to periodontal infection. }\end{array}$ \\
\hline Rai B et al. [17] & GCF by ELISA & $\begin{array}{c}\text { Crevicular MMP-2 levels in periodontitis subjects were lower than } \\
\text { those in gingivitis and healthy subjects. The result suggested that } \\
\text { crevicular MMP-2 and 9 may serve as biomarkers of periodontal } \\
\text { disease and aid in early detection of periodontitis or gingivitis. }\end{array}$ \\
\hline Bosca AB et al. [18] & Saliva By ELISA & $\begin{array}{c}\text { All the clinical parameters and MMP-8 salivary levels were } \\
\text { significantly higher in chronic periodontal patients compared to the } \\
\text { healthy subjects }\end{array}$ \\
\hline Goncalves PF et al. [19] & GCF by Immunofluorometric kits & $\begin{array}{c}\text { They found marked reduction of MMP-1, 8,9,12 and 13 levels } \\
\text { following periodontal treatment. They concluded that treatment } \\
\text { of localized aggressive periodontitis was effective in reducing the } \\
\text { levels. }\end{array}$ \\
\hline Javaid et al. [20] & Tissue by ELISA & $\begin{array}{c}\text { Platelet Factor4 up regulates MMP-1 expression in HGFs in a p44/42 } \\
\text { MAPK-dependent manner. }\end{array}$ \\
\hline
\end{tabular}

\section{Estimation of MMPs in Periodontal Disease}

Matrix metalloproteinases can also process various bioactive non matrix substrates, such as cytokines, chemokines, growth factors and immune mediators, thereby mediating both anti and pro-inflammatory processes. Therefore, the levels of matrix metalloproteinases should not be interpreted solely as surrogate markers of tissue destruction but also as part of physiological or anti-inflammatory defense [21]. Based on these biochemical or immunological findings, the oral fluids have been a target for extensive research on diagnostic utilization of MMPs and their regulators as potential candidates in chair-side tests for monitoring periodontal and peri-implant diseases [21]. Samples collected to estimate the levels of different MMPs include- Saliva, GCF, and Tissue sample. Various proteomic techniques are being used to estimate the levels of these MMPs which are listed in Table 2.

Table 2: Proteomics techniques.

\begin{tabular}{|c|c|c|c|}
\hline Technique & Concept & Advantages & Limitations \\
\hline $\begin{array}{l}\text { Two-dimensional } \\
\text { polyacrylamide gel } \\
\text { electrophoresis }\end{array}$ & $\begin{array}{l}\text { Proteins are separated by iso electric focusing } \\
\text { and then by molecular weight by sodium } \\
\text { dodecylsulfatepolyacrylamide gel electrophoresis. } \\
\text { Proteins in spots are cut out, digested to peptides } \\
\text { with trypsin and peptides are identified by mass } \\
\text { spectrophotometry. }\end{array}$ & $\begin{array}{l}\text { Does not require sophisticated } \\
\text { equipment. Inexpensive. } \\
\text { Allows profiling of proteins }\end{array}$ & $\begin{array}{l}\text { Gel to gel variation makes } \\
\text { comparison of different samples } \\
\text { difficult. Large number of technical } \\
\text { replicates is required. Not } \\
\text { quantitative. }\end{array}$ \\
\hline $\begin{array}{l}\text { Two- dimensional } \\
\text { difference in gel } \\
\text { electrophoresis }\end{array}$ & $\begin{array}{l}\text { Samples are labeled with different CyDye fluorescent } \\
\text { dyes (Cy 2, } 3 \text { 5) and are compared on a single gel. }\end{array}$ & $\begin{array}{l}\text { Allows comparison of three } \\
\text { samples on the same gel. } \\
\text { Increased sensitivity }\end{array}$ & $\begin{array}{l}\text { Not all proteins are separated well- } \\
\text { eg very high or low iso-electric } \\
\text { points and membrane proteins. }\end{array}$ \\
\hline $\begin{array}{l}\text { Quantitative shotgun } \\
\text { proteomics }\end{array}$ & $\begin{array}{l}\text { Each sample is labeled with a different isotopic tag, } \\
\text { allowing samples to mixed and analyzed together for } \\
\text { direct comparison of protein levels. }\end{array}$ & $\begin{array}{l}\text { Multiple samples are analyzed } \\
\text { simultaneously. Increased } \\
\text { reproducibility. }\end{array}$ & $\begin{array}{l}\text { Expensive. Complicated data } \\
\text { analysis. }\end{array}$ \\
\hline $\begin{array}{l}\text { Terminal amine } \\
\text { isotopic labeling of } \\
\text { substrates }\end{array}$ & $\begin{array}{l}\text { Quantitative shotgun proteomics with an additional } \\
\text { step: isobaric tags for relative and absolute } \\
\text { quantization labeling occurs at the protein level and } \\
\text { blocks lysines and N termini that are removed using } \\
\text { an amine-reactive polymer }\end{array}$ & $\begin{array}{l}\text { Polymer removal of internal } \\
\text { tryptic peptides simplifies the } \\
\text { sample, leaving the original } \\
\text { N-terminal for analysis. This } \\
\text { facilitates the study of } \mathrm{N}- \\
\text { terminal protein processing } \\
\text { and modification. }\end{array}$ & $\begin{array}{l}\text { There are few } \mathrm{N} \text { - terminal } \\
\text { peptides per protein (original } \\
\text { and neo-N-termini are generated } \\
\text { by proteolysis) which decreases } \\
\text { confidence in identification }\end{array}$ \\
\hline
\end{tabular}

\section{Role of MMP Inhibitors in Periodontal Disease}

A disturbed balance between MMPs and TIMPs might contribute to the disease process in degenerative diseases. Similar patterns of MMP and TIMP expression can be found in different diseases involving matrix degradation. In some cases, the occurrence of MMPs and TIMPs in body fluids such as saliva, gingival crevicular fluid (GCF), or serum provides additional information about the progression of the disease. In healthy periodontal tissue, TIMP levels are generally higher than in inflamed periodontal tissue, in which MMP levels exceed TIMP levels. The more severe the inflammation, the higher the concentrations of active MMPs. In GCF and in gingiva from humans, MMP-1, -2, -3 , and -9 are significantly increased, whereas TIMP-1 and -2 are significantly decreased. The inhibition of MMP expression or activity, or increased TIMP expression, might reduce tissue destruction in periodontitis. 
Different inhibitors include [22]:

a. Alpha 2- macroglobulins

b. Tissue inhibitors of metalloproteinases

c. Inhibiting antibodies

d. Synthetic inhibitors

Endogenous or natural inhibitors such as tissue inhibitors of matrix metalloproteinases and Alpha 2-macroglobulin bind in a non-covalent fashion to members of the matrix metalloproteinase family. TIMPS probably control matrix metalloproteinase activities pericellularly, whereas Alpha 2-macroglobulin functions as a regulator in body fluids. During inflammation, however, the latter high-molecular-weight protein may escape the vasculature and also function in the extracellular matrix [10]. Multiple synthetic peptides have been formulated in an attempt to synthesize more specific chelators including phosphorus containing peptides, sulfur-based inhibitors and peptidyl hydroxamic acid derivatives.

The most widely used synthetic peptides, and the ones receiving the most attention as potential pharmaceutical agents, are the hydroxamic acid derivative. Synthetic Inhibitors of MMPs fall into three pharmacologic categories [23]:

Table 3: Studies Pertaining to MMPs inhibitors. a. Collagen peptidomimetics and non peptidomimetics, Peptidomimetic MMP Inhibitors- Batimastat, Marimastat Nonpeptidic MMP Inhibitors - BAY 12-9566, AG3340, BMS275291, CGS-27023A

b. Tetracycline derivatives- Doxycycline, Col-3 (metastat)

c. Bisphosphonates (Figure 1).

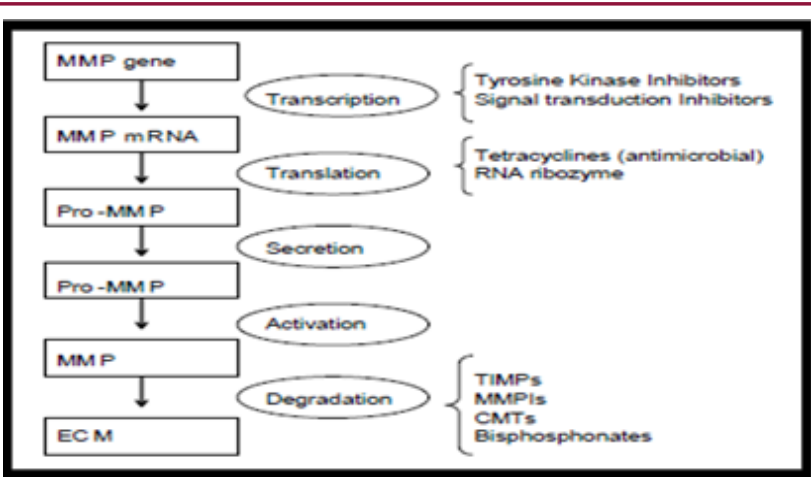

Figure 1: Action of various inhibitors at different levels [24].

Various studies have been done to evaluate the effect of TIMPs on periodontium. Few of them are listed in Tables $3 \& 4$.

\begin{tabular}{|c|c|c|}
\hline Author and Year & Inhibitor & Conclusion \\
\hline Kubota et al. [25] & TIMP-1,2 & Tissue inhibitors of metalloproteinase-1 and -2 (42) messenger RNA expressing cells are at higher \\
levels in the periodontitis than in mild gingivitis
\end{tabular}

Table 4: Various MMPs and their inhibitors.

\begin{tabular}{|c|c|c|c|}
\hline Enzyme & MMPs & Cells Express & Inhibited by \\
\hline Collagenase 1 & 1 & Endothelial cells, fibroblast, basal keratinocyte, macrophage & Batimastat, Marimastat \\
\hline Collagenase 2 & 8 & Neutrophils, endothelial cells, fibroblast & Marimastat, CP471 \\
\hline Collagenase 3 & 13 & Fibroblast & Marimastat, AG3340, CP471 \\
\hline Collagenase 4 & 18 & - & \\
\hline Gelatinase A & 2 & Endothelial cells, fibroblast, t cells, platelets & Batimastat, AG3340, BAY, COL3, BMS, CP471 \\
\hline Gelatinase B & 9 & Neoplastic keratinocytes, inflammatory cells, endothelial & $\begin{array}{l}\text { Batimastat, Marimastat, AG3340, BAY, COL 3, BMS, } \\
\text { CP471 }\end{array}$ \\
\hline Stromelysin 1 & 3 & $\begin{array}{l}\text { Endothelial cells , fibroblasts, macrophages, smooth muscle } \\
\text { cells }\end{array}$ & Batimastat, AG3340, BAY, CP471 \\
\hline
\end{tabular}




\begin{tabular}{|c|c|c|c|}
\hline Stromelysin 2 & 10 & Fibroblasts, T lymphocytes & \\
\hline Stromelysin 3 & 11 & fibroblasts & Batimastat, Marimastat \\
\hline Matrilysin 1 & 7 & macrophages & AG3340, CP471 \\
\hline Matrilysin 2 & 26 & B lymphocytes & \\
\hline MT1-MMP & 14 & Fibroblasts, macrophages & \\
\hline MT2-MMP & 15 & Fibroblasts, macrophages & \\
\hline MT3-MMP & 16 & Fibroblasts, macrophages, smooth muscle & \\
\hline MT4-MMP & 17 & Eosinophil, Monocytes, lymphocytes & Marimastat, CP471 \\
\hline MT5-MMP & 24 & Brain specific mainly by cerebellum & \\
\hline MT6-MMP & 25 & Blood leukocytes & \\
\hline Macrophage & 12 & Macrophages & \\
\hline Elastase & 20 & keratinocytes & \\
\hline Enamelysin & 28 & & \\
\hline Epilysin & & & \\
\hline
\end{tabular}

\section{Conclusion}

There is much evidence for the role of matrix metalloproteinases in the destructive processes of periodontal disease distinguishing them as a viable target for a chemotherapeutic approach. The use of a host modulatory agent such as a matrix metalloproteinase inhibitor can assist with conventional treatment for periodontitis and, when used adjunctively, can enhance and make clinical therapeutic responses more predictable in the more susceptible patient.

\section{References}

1. Woessner JF (1962) Catabolism of collagen and non-collagen protein in the rat uterus during post-partum involution. Biochem J 83(2): 304-314

2. Gross J, Lapiere CM (1962) Collagenolytic activity in amphibian tissues: A Tissue culture assay. Proc Natl Acad Sci USA 48(6): 1014-1022.

3. Padmanabhan R, Nicolle L, Patterson Gregg B, Fields Merry L (2012) The history of Matrixmetalloproteinases: milestones, myths and misperceptions. Ann J Physiol Heart Circ Physiol 303(8): H919-H930.

4. Okada Y, Nagase H, Harris ED (1987) Matrix metalloproteinases 1, 2 and3 from rheumatoid synovial cells are sufficient to destroy joints. J Rheumatol 14: 41-42.

5. Osenkowski P, Toth M, Fridman R (2004) Processing, shedding, and endocytosis of membrane type 1-matrix metalloproteinase (MT1-MMP) J Cell Physiol 200: 2-10.

6. Panagiotis A, Koromantzos, Makrilakis K, Dereka X, Offenbacher S, et al. (2012) Effect of non-surgical periodontal therapy on C-reactive protein, oxidative stress, and matrix metalloproteinase (MMP)-9 and MMP-2 levels in patients with type 2 diabetes: A randomized controlled study. J Periodontol 83: 310.

7. Egeblad M, Werb Z (2002) New functions for the matrix metalloproteinases in cancer progression. Nature Reviews-Cancer 2(3): 161-174.

8. Hansen HB, Moore WGI, Bodden MK, Windsor LJ, Decarlo, et al. (1993) Matrix metalloproteinases: A Review. Critical Reviews in Oral Biology \& Medicine 4(2): 197-250.

9. Visse R, Nagase H (2003) Matrix metalloproteinases and tissue inhibitors of metalloproteinases: structure, function and biochemistry. Circ Res 92(8): 827-839.

10. Ryan ME, Golub LM (2000) Modulation of matrix metalloproteinase activities in periodontitis as a treatment strategy. Periodontology 24(1): 226-238.
11. Golub L, Sorsa T, Lee HM, Ciancio S, Sorbi D, et al. (1995) Doxycyclineinhibits neutrophil (PMN)-type matrix metalloproteinases in human adult periodontitis gingiva. J Clin Periodontol 22(2): 100-119.

12. Sorsa T, Uitto VJ, Suomolainen M, Vauhkonen M, Lindy S (1988) Comparison of interstitial collagenases from human gingiva,sulcular fluid and polymorphonuclear leukocytes. J Periodontal Res 23: 386-393.

13. Uitto VJ, Firth J, Nip L, Golub L (1994) Doxycycline and chemically modified tetracyclines inhibit gelatinase A (MMP-2) gene expression in human skin keratinocytes. Ann N Y Acad Sci 732: 140-151.

14. Azmak N, Atilla G, Luoto H, Sorsa T (2002) The effect of subgingival controlled-release delivery of chlorhexidine chip onclinical parameters and matrix metalloproteinase-8 levels in gingival crevicular fluid. Journal of periodontology 73(6): 608-615.

15. Itagaki M, Kubota T, Tai H, Shimada Y, Morozumi T, et al. (2004) Matrix metalloproteinase-1 and-3 gene promoter polymorphisms in Japanese patients with periodontitis. Journal of clinical periodontology 31(9): 764-769.

16. Smith PC, Muñoz VC, Collados L, Oyarzún AD (2004) In situ detection of matrix metalloproteinase-9 (MMP-9) in gingival epithelium in human periodontal disease. Journal of periodontal research 39(2): 87-92.

17. Rai B, Kharb S, Jain R, Anand SC (2008) Biomarkers of periodontitis in oral fluids. Journal of oral science 50(1): 53-56.

18. Boşca AB, Miclăuş V, Raţiu C, Melincovici C (2012) Matrix Metalloproteinase-8-a salivary diagnostic biomarker related to soft tissue distruction in chronic periodontitis. Ann RSCB 17: 251-257.

19. Gonçalves PF, Huang H, Mc Aninley S, Alfant B, Harrison P, et al. (2013) Periodontal treatment reduces matrix metalloproteinase levels in localized aggressive periodontitis. Journal of periodontology 84(12): 1801-1818.

20. Javaid M, Bi J, Biddle C, Tsai CM, Häkkinen L, et al. (2017) Platelet factor 4 upregulates matrix metalloproteinase- 1 production in gingival fibroblasts. Journal of Periodontal Research 52(4): 787-792.

21. Sorsa T, Gursoy UK, Nwhator S, Hernandez M, Tervahartiala T, et al. (2016) Analysis of matrix metalloproteinases, especially MMP-8, in gingival crevicular fluid, mouthrinse and saliva for monitoring periodontal diseases. Periodontology 70(1): 142-163.

22. Hidalgo M, Eckhardt SG (2001) Development of matrix metalloproteinase inhibitors in cancer therapy. Journal of the National Cancer Institute 93(3): 178-193.

23. Ustun K, Alptekin NÖ, Hakki SS, Hakki EE (2008) Investigation of matrix metalloproteinase-1- $16071 \mathrm{G} / 2 \mathrm{G}$ polymorphism in a Turkish population with periodontitis. Journal of clinical periodontology 35(12): 1013-1019. 
24. Acharya MR, Venitz J, Figg WD, Sparreboom A (2004) Chemically modified tetracyclines as inhibitors of matrix metalloproteinases. Drug Resistance Updates 7(3): 195-208.

25. Kubota T, Matsuki Y, Nomura T, Hara K (1997) In situ hybridization study on tissue inhibitors of metalloproteinases (TIMPs) mRNA-expressing cells in human inflamed gingival tissue. Journal of periodontal research 32(5): 467-472.

26. Shibata Y, Takiguchi H, Abiko Y (1999) Antisense oligonucleotide of tissue inhibitor of metalloproteinase- 1 induces the plasminogen activator activity in periodontal ligament cells. Journal of periodontology 70(10): 1158-1165.

27. Tüter G, Kurtiş B, Serdar M (2002) Effects of phase I periodontal treatment on gingival crevicular fluid levels of matrix metalloproteinase-1 and tissue inhibitor of metalloproteinase-1. Journal of periodontology 73(5): 487-493.

28. Ramamurthy NS, Rifkin BR, Greenwald RA, Xu JW, Liu Y, et al. (2002) Inhibition of matrix metalloproteinase-mediated periodontal bone loss in rats: a comparison of 6 chemically modified tetracyclines. Journal of periodontology 73(7): 726-734.

29. Bodineau A, Godeau G, Brousse N, Pellat B, Folliguet M, et al. (2006) Langerhans cells express matrix metalloproteinases 9 and 2 and tissue inhibitors of metalloproteinases 1 and 2 in healthy human gingival tissue and in periodontitis. Molecular Oral Microbiology 21(3): 197-200.

30. Chen D, Wang Q, Ma ZW, Chen FM, Chen Y, et al. (2007) MMP-2, MMP-9 and TIMP-2 gene polymorphisms in Chinese patients with generalized aggressive periodontitis. Journal of clinical periodontology 34(5): 384 389.

31. Cury PR, Canavez F, De Araújo VC, Furuse C, De Araújo NS (2008) Substance $\mathrm{P}$ regulates the expression of matrix metalloproteinases and tissue inhibitors of metalloproteinase in cultured human gingival fibroblasts. Journal of periodontal research 43(3): 255-260.

32. Zeldich E, Koren R, Dard M, Weinberg E, Weinreb M, et al. (2010) Enamel matrix derivative induces the expression of tissue inhibitor of matrix metalloproteinase-3 in human gingival fibroblasts via extracellular signal-regulated kinase. Journal of periodontal research 45(2): 200-206.

33. Johanson M, Zhao XR, Huynh-Ba G, Villar CC (2013) Matrix Metalloproteinases, Tissue Inhibitors of Matrix Metalloproteinases, and Inflammation in Cyclosporine A-Induced Gingival Enlargement: A Pilot In Vitro Study Using a Three-Dimensional Model of the Human Oral Mucosa. Journal of periodontology 84(5): 634-640.

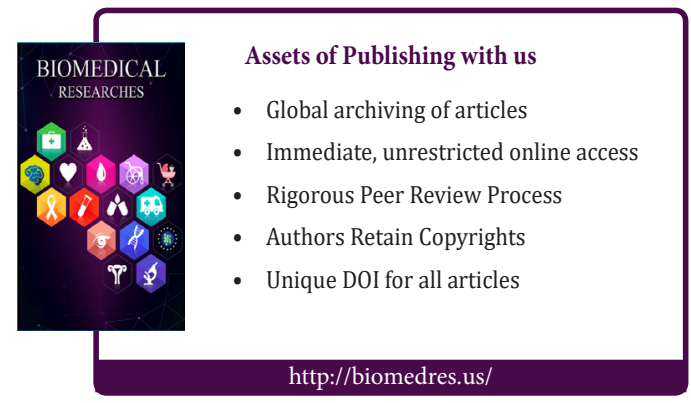

